\title{
Pelatihan Pembuatan Merchandise untuk Meningkatkan Keterampilan dan Kreativitas Masyarakat di Kampoeng Heritage Kajoetangan Malang
}

\author{
Edi Widianto ${ }^{1}$, Annisa Wahyu Rosena ${ }^{2}$, Ayuerma Dilasari ${ }^{3}$, Dia Ajeng Aulia ${ }^{4}$, Sri \\ Wahyuningsih $^{5}$, Tsaniah Zain Ashfahani ${ }^{*}$, Wawan Andriarno ${ }^{7}$ \\ ${ }^{1-7}$ Universitas Negeri Malang \\ ${ }^{*}$ Corresponding author \\ E-mail: tsaniazain08777@gmail.com
}

Article History:

Received: 19-10-2020

Revised: 04-11-2020

Accepted: 12-01-2021
Keywords:

\section{Pendahuluan}

Kampoeng Heritage Kajoetangan merupakan salah satu tempat wisata tematik bertempat di pusat Kota Malang. Kampung wisata ini berlokasi di Kelurahan Kauman Kecamatan Klojen Kota Malang. Kampung wisata yang diresmikan pada tanggal 22 April 2018 ini mengusung tema wisata budaya yang didalamnya terdapat unsur wisata masa lampau dengan menonjolkan bentuk-bentuk bangunan seperti rumah Belanda yang masih dalam keadaan baik sampai sekarang. Kampoeng Heritage Kajoetangan memiliki kurang lebih 30 objek wisata yang menarik untuk dikunjungi, diantaranya yaitu rumah punden, rumah galeri antik yang dipenuhi barang-barang pada zaman dahulu, kuburan tanda, pasar krempyeng, masjid tua pintu 1870, tangga seribu Belanda, dan juga rumah cerobong.

Kampoeng Heritage Kajoetangan tidak hanya menonjolkan arsitektur bangunan peninggalan Belanda saja tetapi terdapat juga beberapa alat-alat antik yang digunakan pada masa lalu. Wisatawan dapat menikmati berbagai spot foto yang ada di wilayah wisata Kampoeng Heritage Kajoetangan. Wisatawan disuguhkan dengan berbagai pemandangan dan juga keindahan spot foto yang dibuat dengan ornamen-ornamen khas pada zaman dahulu, terutama pada zaman 
Belanda. Wisata ini sangat memberi dampak kepada masyarakat sekitar terutama dampak positif dengan berdirinya kampung wisata ini menjadikan Kampung Kayutangan lebih dikenal oleh banyak orang dan dikunjungi para wisatawan baik wisatawan Indonesia maupun luar negeri. Pengembangan pada sektor pariwisata sangat berpotensi untuk kesejahteraan masyarakat dengan melibatkan peran aktif masyarakat dan kelompok sadar wisata (pokdarwis) dalam pengelolaanya. Pada saat sekarang ini pariwisata adalah salah satu sektor yang pendapatannya dapat diandalkan (Mamonto et al., 2016).

Keberhasilan Kampoeng Heritage Kajoetangan Malang diiringi dengan adanya potensi yang dimiliki. Kampung wisata ini merupakan satu-satunya kampung yang mengingatkan wisatawan akan peninggalan zaman Belanda dahulu, sehingga perlunya menjaga dan melestarikan peninggalan-peninggalan bersejarah ini. Melihat kondisi keadaan Kampoeng Heritage Kajoetangan Malang ini merupakan kampung tematik yang banyak digemari oleh para wisatawan. Namun ada beberapa hal yang menjadi kurang di dalam pengelolaan Kampoeng Heritage Kajoetangan Malang yaitu kurangnya kesadaran masyarakat setempat dan keterampilan yang dimiliki oleh masyarakat dalam membuat suatu kerajinan untuk merchandise yang dapat dijual belikan sebagai oleh-oleh khas dari kampung Heritage.

Melihat kondisi tersebut untuk mengembangkan skill masyarakat baik dilihat dari aspek kreativitas, keaktifan, dan ekonomi yaitu salah satu gerakan pendidikan luar sekolah secara ide atau pemikiran maupun praktik secara langsung. Proses ini perlu langkah identifikasi sejak dini demi mendapatkan potensi yang dapat diangkat untuk meningkatkan skill masyarakat tersebut. Salah satunya adalah memberikan pelatihan pembuatan merchandise bagi warga yang berada disekitar wisata Kampoeng Heritage Kajoetangan. Pelatihan itu sendiri adalah serangkaian kegiatan belajar yang meminimalisir penyampaian teori dan lebih memperbanyak jam praktek secara langsung, dengan menggunakan berbagai metode yang bertujuan untuk meningkatkan salah satu skill yang dimiliki oleh individu maupun organisasi (Santoso, 2010). Pelatihan pembuatan merchandise adalah produk-produk yang dijual kepada konsumen dengan memiliki ciri khas tertentu. Pelatihan pembuatan merchandise bertujuan untuk meningkatkan kreativitas dan menumbuhkan jiwa kewirausahaan masyarakat yang ada di Kampoeng Heritage Kajoetangan Malang. Pelatihan merupakan salah satu unsur pendukung pendidikan yang bermanfaat untuk meningkatkan dan memberdayakan sumber daya manusia untuk menjadi lebih unggul (Fatihah, 2017). Dengan masyarakat yang unggul dan berdaya diharapkan bisa menyejahterakan kehidupan masyarakat secara mandiri dengan berwirausaha menjual merchandise yang sudah diajarkan di pelatihan. Kewirausahaan adalah tindakan pemecahan suatu masalah dengan memanfaatkan suatu peluang yang dialami oleh orang setiap hari dengan bentuk inovasi dan kreativitas (Rini et al., 2019). 
Pelatihan pembuatan merchandise ini diharapkan dapat menjadikan masyarakat memiliki potensi sumber daya manusia untuk berwirausaha dan meningkatkan perekonomian, serta memberikan ilmu pengetahuan bagi masyarakat Kampoeng Heritage Kajoetangan Malang tentang merchandise. Merchandise adalah pernak-pernik yang dipakai manusia pada kesempatan acara yang bertujuan untuk mendukung penampilan atau sebagai aksen. Seperti kaos yang tertera sablon yang menggambarkan suatu tempat wisata tertentu, gantungan kunci dan tas. Tujuannya adalah untuk memperkenalkan secara tidak langsung eksistensi keberadaan tempat wisata tersebut kepada masyarakat luas, sehingga masyarakat menjadi tau dan ingin berkunjung ke tempat yang tertera pada pernak-pernik tersebut.

Sasaran dalam kegiatan pelatihan ini adalah masyarakat Kampoeng Heritage Kajoetangan Malang yaitu ibu-ibu bapak-bapak dan para remaja yang ada di wilayah kampung ini. Sesuai dengan permasalahan yang ada maka target yang ingin dihasilkan dari kegiatan pelatihan ini adalah masyarakat memiliki pengetahuan dan keterampilan membuat kerajinan merchandise oleh-oleh khas masyarakat Kampoeng Heritage Kajoetangan Malang. Pelatihan pembuatan merchandise akan diberikan materi dan praktek seputar sablon tas dan juga pembuatan gantungan kunci khas Kampoeng Heritage Kajoetangan Malang serta bagaimana cara mem-branding dan memasarkannya.

\section{Metode}

Pelatihan dapat dianggap sebagai suatu sarana yang berguna untuk meningkatkan pengetahuan, bertambahnya wawasan, keterampilan dan juga kemampuan yang baru pada suatu bidang pekerjaan yang bermanfaat untuk masa yang akan datang (Setiawan \& Hidayat, 2015). Pelaksanaan pelatihan pembuatan merchandise ini adalah suatu bentuk dari pengabdian kepada masyarakat, dengan memberikan pelatihan kepada masyarakat agar memiliki pengetahuan dan kreativitas dalam membuat merchandise untuk nantinya dapat bermanfaat dalam pertumbuhan ekonomi masyarakat. Pelatihan pembuatan merchandise ini melalui tiga tahap, yaitu: (1) Perencanaan, pada tahap ini yang dilakukan adalah mensurvei atau melakukan observasi ke lapangan guna mendapatkan data atau fenomena apa yang sedang terjadi di masyarakat, khususnya masyarakat Kampoeng Heritage Kajoetangan Malang. Melalui beberapa kunjungan dan observasi dapat diketahui permasalahan apa yang sedang terjadi atau kebutuhan apa yang diperlukan di kampung wisata ini. Dalam hal ini penyelenggara bekerjasama dengan pengelola Kampoeng Heritage Kajoetangan Malang. Setelah mengetahui kebutuhan yang dibutuhkan oleh masyarakat setempat maka dalam hal ini penyelenggara pelatihan mempelajari apa yang dibutuhkan dan sekiranya cocok untuk diterapkan khususnya dibidang pembuatan merchandise. Selanjutnya menentukan merchandise yaitu pembuatan sablon dan gantungan kunci dengan persetujuan pengelola Kampoeng Heritage Kajoetangan Malang, (2) Pelaksanaan, langkah ini merupakan langkah pelaksanaan program pelatihan pembuatan merchandise untuk masyarakat 
Kampoeng Heritage Kajoetangan, dan (3) Evaluasi dan Monitoring, tujuannya untuk menilai dan mengukur setiap proses pelatihan berlangsung, pada evaluasi ini juga disajikan sebuah instrumen evaluasi gunanya untuk meminimalisir apabila terjadi kesalahan ataupun ada yang kurang tepat selama proses kegiatan berlangsung. Melalui upaya tersebut panitia pelatihan bisa menilai pada level berapa atau sejauh mana kegiatan pelatihan berlangsung juga untuk melihat sejauh mana pencapaian tujuan yang telah diraih setelah kegiatan pelatihan berakhir.

Setiap pelatihan memiliki macam-macam metode, masing-masing dari metode tersebut memiliki tujuan yang hampir sama, dengan tujuan yaitu agar peserta pelatihan memiliki kemampuan sesuai dengan apa yang sedang dibutuhkan (Handoko, 2000). Metode yang digunakan dalam pelatihan pembuatan merchandise ada tiga, yaitu: (1) Ceramah, dalam metode ini instruktur pelatihan memberikan materi berupa teori seputar teknik menyablon, jenis-jenis sablon, teori tentang gantungan kunci, dan juga teori kiat-kiat berwirausaha; (2) Diskusi, setelah adanya penyampaian secara teori instruktur pelatihan memberikan kesempatan kepada peserta pelatihan untuk bertanya dan berdiskusi bersama seputar materi yang dibahas; (3) Praktik, sesuai nama program yang dilaksanakan adalah pelatihan maka hal yang wajib dilakukan adalah praktik, dalam hal ini instruktur pelatihan memberikan contoh secara langsung dalam membuat sablon dan membuat gantungan kunci, kemudian peserta pelatihan juga diberikan kesempatan untuk mempraktikkan secara langsung secara bergantian. Tentunya itu semua juga memerlukan metode untuk menumbuhkan rasa ingin mencoba bagi peserta pelatihan, sehingga peserta bisa lebih aktif dalam melakukan pelatihan. Keaktifan yaitu kegiatan yang melibatkan fisik maupun mental yang mencakup berbuat dan berpikir merupakan suatu kesatuan yang tidak dapat dipisahkan (Wibowo, 2016). Tujuannya agar peserta pelatihan tidak hanya mendapat materi secara teori tetapi juga secara praktik.

\section{Hasil}

Produk wisata yaitu merupakan salah satu bagian dari penerapan sapta pesona yang berwujud yang dapat disebut dengan kenangan. Dalam hal ini, cinderamata atau merchandise diharapkan mampu dan dapat menjadi kenangan yang berwujud bagi wisatawan yang berkunjung ke suatu daerah tujuan wisata. Produk wisata sebagaimana adalah segala sesuatu yang ditawarkan kepada konsumen yakni wisatawan yang sifatnya menarik, dapat dimiliki, dapat digunakan, serta mampu memberikan kepuasan kepadanya. Praktiknya, produk wisata pun dapat digunakan sebagai penanda seseorang, yakni dapat menunjukkan bahwa seseorang telah melakukan kunjungan wisatawan ke suatu tempat yang ditunjukkan dengan produk wisata yang khas. 
Kegiatan pelatihan pembuatan merchandise dilaksanakan di Kampoeng Heritage Kajoetangan Malang yang bertempat di Jalan Jend. Basuki Rachmat Gg.VI Kauman. Kegiatan ini diikuti oleh 50 peserta yaitu masyarakat yang tinggal di Kampoeng Heritage Kajoetangan serta masyarakat di sekitarnya. Peserta yang mengikuti pelatihan pembuatan merchandise ini terdiri dari ibu-ibu, bapak-bapak serta para pemuda yang ada disana. Pelatihan pembuatan merchandise di Kampoeng Heritage Kajoetangan Malang dilakukan dengan dua sesi pelatihan. Sesi yang pertama yaitu merupakan pelatihan memproduksi merchandise sablon tote bag dan pembuatan gantungan kunci sedangkan sesi kedua yaitu pemaparan materi berupa bagaimana membranding suatu produk agar dapat bernilai jual lebih di pasaran. Setelah kedua tahap selesai maka panitia membagikan angket berupa evaluasi pelatihan yang telah dilaksanakan sebagai bahan koreksi panitia untuk pelatihan kedepannya.

Pelatihan pembuatan merchandise di Kampung Heritage Kajoetangan Malang menghasilkan dua hasil, yaitu hasil non-fisik dan hasil fisik. Hasil Fisik yang dihasilkan dari pelatihan ini ada dua macam yang pertama adalah beberapa alternatif desain yang nanti akan diterapkan menjadi produk merchandise dan produk jadi yang nantinya akan siap dipasarkan. Adapun produk yang akan dihasilkan yaitu berupa sablon tote bag dengan desain khas Kampoeng Heritage Kajoetangan Malang dan gantungan kunci Khas Kampoeng Heritage Kajoetangan Malang dengan kemasan yang dapat meningkatkan nilai jual produk merchandise tersebut. Berdasarkan hasil yang telah dicapai setelah kegiatan pelatihan ini menunjukan bahwa peserta pelatihan sudah mampu mengenal karakteristik bahan dan alat sablon serta alat dan bahan pembuatan gantungan kunci. Peserta juga dapat menggunakan dan membuat langsung dengan sendirinya. Hasil non fisik yang diperoleh dari pelatihan ini adalah hampir semua peserta telah memahami konsep pembuatan merchandise yaitu berupa sablon tote bag dan gantungan kunci serta cara membranding suatu produk agar dapat bernilai lebih yang telah disampaikan oleh pemateri. Ketercapaian dari hasil ini dilihat dari antusias peserta pelatihan saat pelatihan berlangsung. Banyak peserta pelatihan yang bertanya dan ingin praktik langsung untuk mencoba membuat sablon tote bag dan gantungan kunci. Para peserta mampu menangkap materi dengan baik dan dapat memahami setiap paparan yang disampaikan oleh pemateri. Usai dari pelatihan ini berlangsung, peserta dapat memahami bahwasanya dalam membuat suatu produk merchandise untuk oleh-oleh dari kawasan wisata diperlukan pemikiran yang matang hingga menjadi sebuah produk dengan desain yang unik dan banyak diminati oleh masyarakat.

Dari 50 peserta terdapat 10 peserta yang aktif bertanya dan aktif untuk maju bersama pemateri serta berani untuk mencoba langsung membuat sablon tote bag dan gantungan kunci. Antusias warga sangat mendukung dalam keberlangsungan dalam kegiatan pelatihan ini. Banyak warga yang ingin tahu mengenai pembuatan sablon tote bag dan gantungan kunci khas Kampoeng Heritage Kajoetangan 
Malang. Tidak hanya warga setempat yang mengikuti dalam kegiatan ini tetapi masyarakat luar yang tinggal di sekitar Kampoeng Heritage Kajoetangan Malang juga ikut serta dalam pelatihan ini. Setelah pelaksanaan pelatihan seluruh peserta diberikan lembar evaluasi berupa angket yang berisikan aspek-aspek pelatihan dari awal hingga akhir. Evaluasi dimaksudkan untuk perbaikan pelatihan. Panitia dapat mengetahui kekurangan dan kesalahan dalam pelatihan melalui angket yang diisi oleh peserta. Beberapa aspek evaluasi yang perlu mendapat perhatian lebih adalah tempat pelaksanaan pelatihan dan ketepatan waktu. Pelatihan dilaksanakan di Balai RW 1 kelurahan Kauman yang terletak di dalam kawasan kampung wisata. Letaknya yang berada di dalam dan jauh dari jalan raya membuat peserta yang berasal dari luar kesulitan untuk mencari lokasi. Selain itu, daya listrik yang rendah menyebabkan kegiatan pelatihan sempat terhenti karena listrik mati. Pelaksanaan pelatihan juga mundur karena ketua pokdarwis dan perwakilan Dinas Kepemudaan dan Olahraga terlambat hadir. Angket ini juga dapat digunakan sebagai pegangan panitia untuk acuan penyelenggaraan pelatihan yang dimasa depan.

\section{Diskusi}

Kampung wisata heritage merupakan kampung wisata yang sangat terkenal di kota Malang dengan lokasi yang sangat strategis berada di dekat pusat Kota Malang. Berbicara mengenai heritage yang merupakan sebuah kampung seni yang memiliki arti kampung situs warisan budaya maka kita akan berada di tataran sejarah sebuah wilayah. Dalam perkembangannya, heritage menjadi salah satu bagian pembentukan citra suatu wilayah atau yang biasa kita kenal dengan sebutan city branding (Prasetya \& Pujarama, 2019). Dalam sebuah wilayah yang memiliki seni dan dikenal sebagai kampung wisata maka wilayah tersebut harus memiliki sebuah produk yang dapat dijadikan sebagai simbolis atau cinderamata khas yang dimiliki oleh wilayah tersebut. Cinderamata merupakan peluang yang dapat dimanfaatkan untuk menarik minat wisatawan yang secara langsung akan berpengaruh terhadap pendapatan pengelola wisata dan masyarakat setempat (Noviana et al., 2018). Jadi, dengan adanya sebuah produk yang dihasilkan oleh kampung wisata ini, maka kampung wisata ini lebih dikenal lagi selain menjadi kampung wisata juga dikenal sebagai kampung yang memiliki brandingnya sendiri atau produk sendiri. Dengan penamaan Kampoeng Heritage Kajoetangan, berbagai macam simbolisasi Kota Malang dapat diketahui. Sebagai bagian dari aspek pembentuk image Kota Malang yang memberikan sajian sejarah dan budaya, heritage tersebut mampu membentuk citra yang positif. Selain itu aspek pembentuk good governance juga dapat direalisasikan. Selama ini, aspek heritage Kota Malang kurang mendapatkan perhatian dari masyarakat. Namun dengan usaha pemerintah yang dibantu oleh berbagai elemen masyarakat, maka dapat tercipta wahana baru yaitu heritage Kota Malang. 
Pelatihan adalah proses pendidikan jangka pendek yang menggunakan prosedur sistematis. Pada dasarnya, kegiatan pelatihan diberikan sebagai upaya untuk mengembangkan dan memelihara kemampuan serta kesiapan peserta dalam melakukan suatu kegiatan (Turere, 2013). Pelatihan yang diselenggarakan ini diharapkan mampu mengubah Kampoeng Heritage Kajoetangan Malang menjadi sebuah kampung yang dapat membuat sebuah branding sendiri dan dapat meningkatkan penghasilan masyarakat setempat khususnya yang bertumpu pada kegiatan wisata disini. Selain itu, diharapkan juga agar kampung wisata ini lebih terkenal lagi dan lebih diminati oleh pengunjung lokal maupun dari mancanegara dengan adanya sebuah produk khas wilayah tersebut. Pelatihan pembuatan gantungan kunci dan sablon ini dapat dijadikan sebagai salah satu produk atau brand di Kampoeng Heritage Kajoetangan Malang. Proses pembuatan gantungan kunci dan sablon baju sangatlah mudah.

Melihat potensi yang dimiliki oleh Kampoeng Heritage Kajoetangan, pelatihan ini sangat bisa digunakan sebagai produk branding karena di kampung ini sudah ada beberapa warga yang memiliki usaha sablon tetapi tidak dijalankan secara maksimal karena mereka tidak paham bagaimana cara memasarkan atau membandingkan sebuah produk yang telah dimiliki oleh warga kampung tersebut. Beruntungnya lagi, kampung ini memiliki sebuah organisasi Pokdarwis atau Kelompok Sadar Wisata yang tugasnya mengelola wisata yang ada di sana. Keberadaan Pokdarwis sebagai suatu organisasi lokal yang bertanggung jawab untuk mengelola kampung wisata mempunyai pengaruh dalam keberhasilan pengembangan wisata (Putra, 2013). Mereka memang ditugaskan untuk menjaga seni dan struktur tentang wisata tersebut. Melihat kondisi yang Kampoeng Heritage Kajoetangan yang sudah terkenal namanya di Kota Malang, maka diselenggarakan pelatihan ini. Peluang wirausaha yang terdapat pada suatu kampung wisata sangat besar meningkatkan kebutuhan wisatawan yang bermacam-macam baik berupa barang atau jasa (Yulianto, 2018). Produk produk yang dihasilkan nantinya bisa dijual kepada pengunjung wisata. Dengan begitu, bisa menambah devisa atau menambah penghasilan dari Kampung Wisata Heritage. Produk ini bisa dipasarkan melalui UKM yang ada di Kota Malang dan bisa dijual langsung di tempat dan sebagai tiket masuk agar bisa menarik perhatian pengunjung wisata.

Gantungan kunci berbentuk lingkaran yang memiliki logo dan gambar tentang suasana Kampoeng Heritage Kajoetangan dapat digunakan sebagai produk lokal buatan sendiri. Dengan begitu, dapat menambah pemasukan serta dapat memberikan pekerjaan bagi ibu-ibu yang hanya berstatus sebagai ibu rumah tangga. Tujuan pelatihan ini juga untuk memberdayakan masyarakat yang ada di Kampoeng Heritage Kajoetangan Malang. Pemberdayaan maksudnya adalah upaya untuk meningkatkan kualitas hidup masyarakat serta melepaskan diri dari kemiskinan dan keterbelakangan (Andriyani et al., 2017). Jadi, pelatihan ini sekaligus memberdayakan warga agar mereka bisa belajar mengelola potensi yang mereka miliki. Selain pelatihan pembuatan merchandise, juga ada pelatihan tentang cara 
membranding sebuah produk agar khalayak sasaran atau masyarakat dapat mengenal produk yang dihasilkan.

Dalam komunikasi pemasaran brand bukan sekedar nama dan logo, brand merupakan janji satu organisasi (satuan kerja) kepada pelanggan untuk memberikan apa yang menjadi prinsip brand tersebut. Pembuatan sebuah brand atau logo dalam hal pemasaran produk bertujuan agar sebuah produk yang dihasilkan oleh sebuah komunitas atau organisasi dalam hal ini adalah Pokdarwis yang ada di Kampoeng Heritage Kajoetangan adalah sebagai bentuk ciri khas sebuah produk yang mereka hasilkan yang mencerminkan sebuah produk khas dari kampung ini dan logo pada sebuah branding dapat menjadikan sebuah produk berbeda dengan produk yang lain sehingga khalayak sasaran atau masyarakat dapat membedakan sebuah produk khas dari Kampoeng Heritage Kajoetangan. Manfaat lain dari sebuah branding produk adalah untuk mengantarkan sebuah produk menjadi lebih unggul.

Kampoeng Heritage Kajoetangan sebagai bagian dari pembentukan citra Kota Malang perlu dikaji lebih mendalam. Kita bisa mengetahui image sebuah kota melalui upaya baik disengaja maupun tidak disengaja dari pemerintah kota tersebut untuk meningkatkan reputasi dan image dari sebuah kota yang disebut dengan city branding. City branding bisa diartikan sebagai sebuah strategi untuk meningkatkan keuntungan dengan menyediakan kota-kota dengan gambaran tertentu mulai nilai sosial, ekonomi, politik dan budaya dari kota tersebut (Prasetya \& Pujarama, 2019). City Branding melalui pengembangan kawasan wisata heritage merupakan salah satu bentuk upaya merespon berbagai masalah pembangunan, di mana nilai-nilai tersebut berpengaruh terhadap brand dari kota yang bersangkutan.

\section{Kesimpulan}

Pelatihan pembuatan merchandise yaitu merupakan salah satu bentuk pengabdian kepada masyarakat Kampoeng Heritage Kajoetangan Malang. Sasaran dalam kegiatan pelatihan ini yaitu adalah masyarakat setempat Malang yang terdiri dari ibu-ibu, bapak-bapak serta para remaja yang ada di wilayah kampung wisata ini. Adapun yang dapat dihasilkan dari pelatihan ini adalah sablon tote bag dan gantungan kunci khas Kampoeng Heritage Kajoetangan Malang dengan kemasan yang dapat meningkatkan nilai jual dari produk tersebut. Berdasarkan hasil setelah mengikuti kegiatan pelatihan disini terlihat bahwa peserta pelatihan sangat antusias dalam mengikuti pelatihan dan hampir semua peserta pelatihan telah memahami konsep pembuatan merchandise. Peserta ikut mempraktekkan secara langsung step by step materi yang telah disampaikan pemateri dan adanya respon positif dari masyarakat dengan materi pelatihan pembuatan merchandise. 


\section{Pengakuan/Acknowledgements}

Ucapan terima kasih disampaikan kepada semua pihak yang telah berperan baik secara langsung maupun tidak langsung dalam penyelenggaraan Pelatihan Pembuatan Merchandise kepada: 1) Lembaga Penelitian dan Pengabdian kepada Masyarakat, Universitas Negeri Malang; 2) Bapak Dr. Zulkarnain, M.Pd., M.Si selaku Ketua Jurusan Pendidikan Luar Sekolah, Fakultas IImu Pendidikan, Universitas Negeri Malang; 3) Bapak Rizal Fahmi selaku ketua Kelompok Sadar Wisata (Pokdarwis) di Wisata Kampoeng Heritage Kajoetangan, Kota Malang; 4) Seluruh anggota Pokdarwis dan masyarakat sekitar Wisata Kampoeng Heritage Kajoetangan yang telah berpartisipasi dalam kegiatan pengabdian kepada masyarakat dalam bentuk pelatihan pembuatan merchandise.

\section{Daftar Referensi}

Andriyani, A. A., Martono, E., \& Muhammad. (2017). Pemberdayaan Masyarakat melalui Pengembangan Desa Wisata dan Implikasinya terhadap Ketahanan Sosial Budaya Wilayah. Jurnal Ketahanan Nasional , 1-16.

Fatihah, E. M. (2017). Efektifitas Diklat DTSS PBJ dalam Menunjang Kinerja. Jurnal Pendidikan Nonformal , 110-125.

Handoko, H. (2000). Manajemen Personalia dan Sumber Daya Manusia. Yogyakarta: BPFE.

Mamonto, N., Gosal, T. R., \& Singkoh, F. (2016). Pemberdayaan Masyarakat dalam Menunjang Sektor Pariwisata sebagai Pendukung Perekonomian. Jurnal Studi llmu Pemerintahan, 1-9.

Noviana, Z. R., Choiriyah, W., \& Purnomo, R. A. (2018). Pengembangan Ekowisata Gunung Beruk dan Pembuatan Cinderamata dari Potensi Alam Sekitar berbasis Pemberdayaan Masyarakat. Seminar Nasional dan Call for Paper III (pp. 534-539). Ponorogo: Universitas Muhammadiyah Ponorogo.

Prasetya, A. B., \& Pujarama, W. (2019). Kiprah Heritage sebagai Simbolisasi City Branding dan Good Governance: Studi Semiotika Komunikasi Publik pada Kampoeng Heritage Kajoetangan sebagai Bagian City Branding Kota Malang. Jurnal IImiah Dinamika Sosial , 234-244.

Putra, T. R. (2013). Peran Pokdarwis dalam Pengembangan Atraksi Wisata di Desa Wisata Tembi Kecamatan Sewon Kabupaten Bantul. Jurnal Pembangunan Wilayah dan Kota , 225-235.

Rini, D. R., Hidayat, I. K., \& Lose, Y. A. (2019). Pelatihan Pembuatan Desain Merchandise Kampung Warna-Warni pada Penduduk Kampung Jodipan untuk Meningkatkan Semangat Kewirausahaan. Jurnal Karinov , 9-14. 
Santoso, B. (2010). Skema dan Mekanisme Pelatihan: Panduan Penyelenggaraan Pelatihan. Depok: Yayasan Terumbu Karang Indonesia.

Setiawan, V., \& Hidayat, R. (2015). Pengaruh Metode Pelatihan terhadap Kompetensi Karyawan NDT (Non Destructive Test) pada PT. XYZ. Jurnal Akuntansi, Ekonomi dan Manajemen Bisnis , 142-149.

Turere, V. N. (2013). Pengaruh Pendidikan dan Pelatihan terhadap Peningkatan Kinerja Karyawan pada Balai Pelatihan Teknis Pertanian Kalasey. Jurnal EMBA , 10-19.

Wibowo, N. (2016). Upaya Peningkatan Keaktifan Siswa melalui Pembelajaran berdasarkan Gaya Belajar di SMK Negeri 1 Saptosari. Journal Electronics, Informatics and Vocational Education (ELINVO) , 128-139.

Yulianto. (2018). Potensi Desa Wisata dalam Menumbuhkan Peluang Wirausaha dan Pengelolaan Lingkungan. Journal Student UNY, 459-470. 